\title{
The Islamic Quest for Democracy, Pluralism, and Human Rights
}

\author{
Ahmad S. Moussalli \\ Gainesville: University Press of Florida, 2001. 226 pages.
}

In a sequel to his earlier Moderate and Radical Islamic Fundamentalism: The Quest for Modernity, Legitimacy, and the Islamic State, Moussalli makes a 
claim to highlight and, where possible, construct the important ideological and religious arguments on democracy, pluralism, and human rights, as these principles continue to be developed by modern Islamic political discourses. He maintains that by linking classical and medieval Islamic thought with present political and religious debates, Islamic discourses, at least in their socalled moderate versions, have both absorbed and Islamized western values. They have come, therefore, to "constitute a theology of liberation and an epistemological break with the past."

The basic argument that Moussalli attempts to present is both simple and grand. Islamic jurisprudence, philosophy, and theology protect individual and communal rights and legitimize political, social, economic, intellectual, and religious differences, while providing the grounds for viewing the people as the ultimate source of political sovereignty. While the history of the highest Islamic political institution - the caliphate - is mostly one of authoritarianism, classical and medieval Islamic political thought, in contrast, incorporated the seeds of such notions as democracy, pluralism, and human rights together with comparable doctrines of equality, freedom, and justice. Hence, Moussalli's purpose is to emphasize the distinction between Islam as a religious belief system and the Islamic state as a human construct. Such a distinction, he alleges, would provide for limitless possibilities of interpretation and reinterpretation, construction as well as deconstruction. It would further allow for "humanizing the divine" as a means of establishing harmony and cooperation with the West.

Each of the first three chapters begin with a short introduction and analysis to the relevant classical and medieval notions of Muslim political thought. This is followed, respectively, by a review of modern moderate and radical Islamist discourses, as developed from and beyond earlier theoretical and normative Muslim thought, about the perceived compatible western notions. Chapter 1 examines the various concepts of shura (counsel), ikhtiyar (choice), baysah (oath of allegiance), and ijma> (consensus of the Muslim community), which are presented as being the theoretical methods that should govern in political rule.

Chapter 2 considers the Islamic understanding of ikhtilaf, understood in the modern context as the equivalent of pluralism and tolerance. Chapter 3 highlights earlier Islamic conceptions of al-huquq al-shar iyah, (lawful rights) as the framework within which modern conceptions of human rights may be understood. Finally, and in conclusion, chapter 4 attempts to provide a theoretical assessment of the prospects of ongoing Islamic dialectics on democracy, pluralism, and human rights. 
Moussalli's book resorts to the rather common tactic of selectively using Islamic historical material to fit, prove, and ultimately arrive at a preconceived conclusion. This conclusion is not profoundly different from free-floating calls to implementing, adopting, or adapting to western values covered under the veneer of Islamic respectability. Constraining himself with western methodology and doctrines, Moussalli divides Islamist groups into moderates and radicals, thereby creating dichotomies in the Islamic religious field and providing ammunition for those who ascribe to the "many Islams" thesis. Such "artifacts" remain contentious, since too much labeling and qualification ultimately only undermines the very category of Islam and its autonomy. Subsequent arguments would henceforth build and develop on the basis of an "unknown."

While Moussalli makes a valid point in distinguishing between Islamic religious beliefs and Muslim state constructs, this can be done legitimately only within a clear and autonomous contextual framework of contingency and necessity. True, the Islamic state may be perceived as a human approximation, but one whose branches are derived from and defined in terms of a deep-rooted religious worldview. Significantly, this makes it less than a sacred structure, and yet, at the same time, more than a mere human construct. Yet a claim to the "unlimited possibilities" of interpretations and reinterpretations is made without setting the methodological constraints that would limit interpretations from being misinterpretations or falsifications. Nor is due attention given to the overwhelming and dominating secular environment and worldview within which such a process of ijtihad would be conducted. The book's very title, as a matter of fact, sets western values as necessary and Islamic understandings and interpretations as contingent. One cannot help but wonder as to what alternative premises, arguments, conclusions, or reactions would such a book have elicited were it to reorder its title in terms of a democratic, pluralistic, and human rights quest for Islam?

While an Islamic perspective may comprehend the relationship between religion and politics as one where the latter is an imperfect human translation of the former, Moussalli, in contrast, states that the divine can only be understood through the political, and hence "humanizing the divine turns into a source of cooperation." This, however, seems to ignore that the most destructive forms of human conflict in history, whether Nazi, communist, or liberal-democratic, were secular, where the divine already had been humanized. Moussalli's claims do not withstand empirical testing.

Such epistemological inaccuracies allow him to imply strongly that shura and democracy are almost synonymous, thereby ignoring the respec- 
tive religio-scriptural and secular-popular foundations of both. These counterdistinctions cannot be overlooked or reconciled by simply - and rather inaccurately - claiming that people are the ultimate source of sovereignty when their individual and collective role is that of vicegerency (khilafah). This means that people's role and purpose derives from a permanent covenant with God, not a temporary contract that they can change at will.

In the former case, when a people rupture the necessary connection between divine law and their purpose of existence (some may call this secularism), the covenant is broken and their right to representation/vicegerency is no more. This is why apostasy is considered a capital crime - not because it is a betrayal of the Islamic state, as Moussalli seems to suggest, but because it unrightfully breaks the bay ah (the covenant with God). Bay ah, whether divine, political, or even conjugal, can be revoked only by Him/him to whom the oath of allegiance is made, not by the giver. Therefore, sovereignty belongs to God, the imam, or the husband, respectively, not to human beings, the people, or the wife (it should be noted that in contrast to absolute divine sovereignty, human sovereignty is relative and derivate, understood in this context in terms of the right to veto powers, whether in the positive or negative sense).

The choice of people in authority, such as presidents, local governors, rulers, or emirs, is a derivative right of choice by the people. Thus in an Islamic system, people are the source of authority, not of legitimacy or sovereignty. This is a critical and substantive difference from contractual democracy. Yet a detailed discussion of the Iranian case, which may be claimed to approximate this, is nowhere to be seen in Moussalli's book. Where it is mentioned, it is only in passing. Nor does Moussalli seem to clarify the distinctions between contract (aqd ikhtiyar; e.g., presidential election) and covenant ('ahd bay ah; e.g., selection of the faqih). Perhaps it did not fit into his predesigned conclusions, or perhaps he simply perceived them as synonymous.

Furthermore, as the book's title imposes an Islamic quest for particular values, those values are made to appear to be some kind of panacea. Yet the very values of pluralism and tolerance, for instance, and by Moussalli's own admission, proved disastrous for the Ottoman Empire. Those very values allowed the European powers to use and manipulate the millet system to undermine the Empire and establish dominating footholds within it. When a sultan chose to crack down on rebellious non-Muslim minorities to preserve the Empire's integrity, he was accused of despotism and authoritarianism, which then was used to justify European intervention. 
Moussalli fails to show how the values of democracy and human rights may provide for different outcomes. He clearly seems to attribute the West's power to those values, and yet there is always the contentious question as to whether they were really the causes of its ascendancy or the effects of discovering a New World with all of the resources that accompanied it. After all, it could be argued that the dynamics of western preeminence existed at times of absolute monarchs and sovereigns.

Moussalli's intentions in writing this book are undoubtedly benign. However, unless clear and autonomous epistemological, methodological, and hermeneutic boundaries are set from within Islamic sources, and preconceived or presought conclusions are not entertained, concerned scholars will continue to operate in a never-ending vicious circle. Before seeking to join the East and the West, it is more important to bring the East together. Perhaps this is what needs to be done first, instead of expending too much energy in the futile effort of bringing together what, in fact, only can stay apart.

Amr G. E. Sabet

Visiting Associate Professor Department of Social Sciences

Halmstad University Halmstad, Sweden 